Anuario de la Facultad de Derecho. Universidad de Extremadura 36 (2020): 125-163 ISSN: 0213-988X - ISSN-e: 2695-7728

Doi: https://doi.org/10.17398/2695-7728.36.125

\title{
LA LIMITACIÓN PROPORCIONADA DE LOS DERECHOS FUNDAMENTALES: PROBLEMAS CONSTITUCIONALES Y APORTES DE LA PROPORCIONALIDAD
}

THE PROPORTIONED LIMITATION OF FUNDAMENTAL RIGHTS: CONSTITUTIONAL PROBLEMS AND CONTRIBUTIONS OF PROPORTIONALITY

\author{
LORENA CHANO REgAÑa
}

Universidad de Extremadura

Recibido: 04/11/2020 Aceptado: 18/12/2020

\section{RESUMEN}

El presente trabajo ofrece un análisis crítico de las implicaciones de la exigencia constitucional de proporcionalidad en la adopción de medidas restrictivas de derechos fundamentales a partir de una metodología jurídica. Con este objetivo se visibilizará la problemática constitucional del desarrollo legislativo del derecho de excepción en España en el contexto del estado de alarma decretado para hacer frente a la emergencia sanitaria del virus COVID-19 y se analizarán los aportes de la proporcionalidad como límite y garantía de los derechos y libertades de las personas frente a la insuficiencia legislativa del derecho de excepción.

Palabras clave: limitación, derechos fundamentales, proporcionalidad, derecho de excepción, estado de alarma. 
ABSTRACT

This work offers a critical analysis of the implications of the constitutional requirement of proportionality in the adoption of restrictive measures of fundamental rights based on a legal methodology. With this objective in mind, the constitutional problems of the legislative development of the right of exception in Spain will be made visible in the context of the state of alarm decreed to face the health emergency of the COVID-19 virus. In addition, the contributions of proportionality will be analyzed as a limit and guarantee of the rights and freedoms of people in the face of the legislative insufficiency of the right of exception.

Keywords: limitation, fundamental rights, proportionality, right of exception, state of alarm.

Sumario: 1. Introducción. 2. Planteamiento del problema. 3. Estado de alarma y limitación de derechos. 4. La necesidad de un derecho de excepción para limitar derechos fundamentales. 5. El estado social y democrático de derecho: Los derechos fundamentales como límite y garantía frente a los poderes públicos. 6. El principio de proporcionalidad. 6.1. El fundamento constitucional de la proporcionalidad. 6.2. La operatividad de la proporcionalidad como "límite de límite de los derechos fundamentales". 7. Aportes de la proporcionalidad en la adopción de las medidas restrictivas de los derechos. 8. Conclusiones.

\section{INTRODUCCIÓN}

La emergencia sanitaria del virus COVID-19 ha impactado de lleno en la sociedad global provocando efectos transformadores en el orden económico, social, político y medioambiental. Estos cambios suponen un desafío al estado de derecho, a la división de poderes y a la protección de los derechos fundamentales.

En este contexto, la normativa del derecho de excepción en España y la posibilidad de limitar o suspender derechos bajo su régimen han sido muy cuestionadas, generando una polémica sobre la viabilidad jurídico-constitucional del estado de alarma para restringir la libertad de movimiento, el derecho de reunión y la libertad de empresa. En concreto, se ha cuestionado si procedía un 
estado de alarma o un estado de excepción'1; asimismo, se ha discutido si las restricciones operadas por el estado de alarma eran acordes a la limitación de derechos que permite esta fórmula, o si, más bien, estábamos ante una suspensión general ${ }^{2}$.

Las opiniones especializadas en derecho público han sido diversas, pero coinciden mayoritariamente en la exigencia de "proporcionalidad" para adoptar medidas limitativas de los derechos y libertades públicas. Sólo de esta forma puede estar justificada la interferencia de la autoridad gubernativa en el ámbito de libertad de las personas. Así, el profesor Francisco Velasco Caballero ha calificado a la proporcionalidad como "el verdadero eje jurídico de las situaciones de emergencia"3. Otros autores han enfatizado el hecho de que el principio de proporcionalidad, junto al principio de necesidad y a los valores democráticos en una situación excepcional, es el mecanismo que garantiza la no desaparición del derecho4. En términos similares se ha pronunciado el propio Tribunal Constitucional, al dotar a la proporcionalidad de un papel protagónico como límite a la injerencia de los poderes públicos en los derechos fundamentales5. Pero, ¿qué es exactamente la proporcionalidad y qué implicaciones tiene exigirla para la viabilidad constitucional de las medidas restrictivas de derechos? ¿Cuándo estamos ante una medida limitativa de derechos proporcionada? O, en otras

1 Afirmando la conveniencia del estado de alarma: Miguel Ángel Presno Linera, "Fortalezas y debilidades del Derecho de excepción frente al COVID-19”, Jueces para la democracia 99 (2020): 39-48. También, vid. Alfonso García Figueroa, "Estado de alarma, estado de excepción y libertad de circulación", Almacén de Derecho, 8 de abril de 2020, acceso el 18 de diciembre de 2020, https://almacendederecho.org/estadode-alarma-estado-de-excepcion-y-libertad-de-circulacion La postura contraria la podemos encontrar en: Alfonso Cuenca Miranda, “Alarma excepcional”, Papeles FAES 236 (2020): 3-6.

2 Mariano Bacigalupo Saggese, "Estado de alarma y confinamiento domiciliario: sí, es lícito", Fundación Fide: COVID-19, 26 de marzo de 2020, acceso el 18 de diciembre de 2020, https://www.fidefundacion.es/Estado-de-alarma-y-confinamiento-domiciliario-si-es-licito_a1232.html En sentido contrario, vid. Manuel Aragón Reyes, "Hay que tomarse en serio la Constitución”, El País, 10 de abril de 2020, acceso el 18 de diciembre de 2020, https://elpais.com/elpais/2020/04/o9/opinion/1586420090_736317.html 3 Francisco Velasco Caballero, "Confinamientos autonómicos: el caso de Lleida", Blog de Francisco Velasco. Blog independiente, 13 de julio de 2020, acceso el 18 de diciembre de 2020, https://franciscovelascocaballeroblog.wordpress.com/2020/07/13/confinamientos-autonomicos-el-caso-de-lleida/ 4 Pablo Fernández de Casadevante Mayordomo, La defensa de la Constitución. El derecho de emergencia constitucional y el artículo 55 CE (Madrid: Aranzadi, 2020), 69-77. Asimismo, cfr. Pablo Fernández, Casadevante Mayordomo, "El derecho de emergencia constitucional en España: hacia una nueva taxonomía”, Revista de Derecho Político 107 (2020): 111-145.

5 Tribunal Constitucional (Pleno). Sentencia núm. 84/2013, de 11 de abril, Fundamento Jurídico (en adelante, FJ) 6. 
palabras, ¿̇cuándo la restricción del derecho está justificada por ser proporcional? Es más, ¿̇la proporcionalidad debe ser un requisito imprescindible en la adopción de medidas gubernativas y en la producción legislativa o es sólo un medio de control judicial para impedir el abuso y la discrecionalidad del resto de poderes públicos? ¿Qué aporta la proporcionalidad al derecho de excepción?

En el presente trabajo se pretende responder a todas estas cuestiones a partir de una delimitación del marco normativo operable en el derecho de excepción y del principio de proporcionalidad como límite y garantía de la injerencia de los poderes públicos en los derechos y libertades ciudadanas. El objeto final es visibilizar la problemática constitucional del desarrollo legislativo del derecho de excepción en España y analizar los aportes de la proporcionalidad como límite y garantía de los derechos y libertades de las personas frente a la insuficiencia legislativa del derecho de excepción.

\section{PLANTEAMIENTO DEL PROBLEMA}

El pasado 14 de marzo de 2020 se decretó por segunda vez en la historia de la Constitución de 1978 el estado de alarma en España ${ }^{6}$, prorrogado en seis ocasiones hasta tener su fecha de fin el 21 de junio de 20207. Durante todo este

6 Real Decreto 463/2020, de 14 de marzo, por el que se declara el estado de alarma para la gestión de la situación de crisis sanitaria ocasionada por el COVID-19 (Boletín Oficial del Estado, en adelante, BOE núm. 67 de 14 de marzo de 2020).

7 Primera prórroga decretada por el Real Decreto 476/2020, de 27 de marzo, por el que se prorroga el estado de alarma declarado por el Real Decreto 463/2020, de 14 de marzo, por el que se declara el estado de alarma para la gestión de la situación de crisis sanitaria ocasionada por el COVID-19, BOE núm. 86, de 28 de marzo de 2020. Segunda prórroga decretada por Real Decreto 487/2020, de 10 de abril, por el que se prorroga el estado de alarma declarado por el Real Decreto 463/2020, de 14 de marzo, por el que se declara el estado de alarma para la gestión de la situación de crisis sanitaria ocasionada por el COVID-19, BOE núm. 101, de 11 de abril de 2020. Tercera prórroga decretada por el Real Decreto 492/2020, de 24 de abril, por el que se prorroga el estado de alarma declarado por el Real Decreto 463/2020, de 14 de marzo, por el que se declara el estado de alarma para la gestión de la situación de crisis sanitaria ocasionada por el COVID-19, BOE núm. 115, de 25 de abril de 2020. Cuarta prórroga decretada por el Real Decreto 514/2020, de 8 de mayo, por el que se prorroga el estado de alarma declarado por el Real Decreto 463/2020, de 14 de marzo, por el que se declara el estado de alarma para la gestión de la situación de crisis sanitaria ocasionada por el COVID-19, BOE núm. 129, de 9 de mayo de 2020. Quinta prórroga decretada por el Real Decreto 537/2020, de 22 de mayo, por el que se prorroga el estado de alarma declarado por el Real Decreto 463/2020, de 14 de marzo, por el que se declara el estado de alarma para la gestión de la situación de crisis sanitaria ocasionada por el COVID-19, BOE núm. 145, de 23 de mayo de 2020. Y, sexta prórroga decretada por el Real Decreto 555/2020, de 5 de junio, por el que se prorroga el estado de alarma 
período ha estado vigente el ordenamiento jurídico con los límites y las competencias extraordinarias del régimen de excepción, derivado de la previsión constitucional del art. 116.2 de la Constitución (en adelante, $\mathrm{CE}^{8}$ ) y de su desarrollo legislativo a partir de la Ley Orgánica 4/1981, de 1 de junio, de los estados de alarma, excepción y sitio (en adelante, LO 4/1981)9, a lo que hay que sumar lo establecido en los arts. 162 a 165 del Reglamento del Congreso sobre su proceso de aprobación ${ }^{10}$.

Durante este período y con posterioridad al mismo, debido a la adopción de restricciones específicas en distintos territorios amparadas en el fin de protección de la salud pública, se han planteado diversos problemas constitucionales que giran desde diferentes perspectivas en torno a la legitimidad constitucional de la limitación de los derechos fundamentales de las personas y que resumimos como sigue:

Primero. Si las limitaciones derivadas de la declaración del estado de alarma eran las adecuadas a esta fórmula de derecho extraordinario o si, por el contrario, nos encontrábamos más bien ante una suspensión general más propia de la figura del estado de excepción.

Dentro de este ítem, a su vez, se podrían plantear dos cuestiones problemáticas:

Una, si el desarrollo legislativo del estado de alarma por el Real Decreto 463/2020 establecía una limitación de derechos o una suspensión general en toda regla.

Dos, si la restricción del derecho a la libertad deambulatoria (art. 19 CE) conllevaba de suyo una suspensión general de carácter tácito respecto a otros derechos no mencionados en el Real Decreto 463/2020 por el que se declaraba

declarado por el Real Decreto 463/2020, de 14 de marzo, por el que se declara el estado de alarma para la gestión de la situación de crisis sanitaria ocasionada por el COVID-19, BOE núm. 159, de 6 de junio de 2020.

8 BOE núm. 311, de 29 de diciembre de 1978.

9 BOE núm. 134, de 5 de junio de 1981.

10 Resolución de 24 de febrero de 1982 por la que se ordena la publicación en el Boletín Oficial del Estado del nuevo Reglamento del Congreso de los Diputados, BOE núm. 55 de 5 de marzo de 1982. 
el estado de alarma (por ejemplo, derecho de manifestación, derecho de huelga, libertad religiosa y de culto o, derecho de sufragio activo).

Segundo. Si una vez levantado el estado de alarma, y ante la necesidad de preservar la salud pública en una situación de emergencia sanitaria contrastable a partir de los datos del Ministerio de Sanidad y de las diversas Consejerías de Salud autonómicas u órganos equivalentes, se pueden adoptar medidas restrictivas por el Gobierno central y, en su caso, por las autoridades autonómicas y locales que interfieran en los derechos fundamentales de las personas a partir de la cobertura de leyes ordinarias, tales como la Ley 3/1986, de 14 de abril, de medidas especiales en materia de salud pública (en adelante Ley $3 / 1986$ ) ${ }^{11}$ y la Ley 33/2011, de 4 de octubre, general de salud pública (en lo sucesivo Ley $33 / 2011)^{12}$, o leyes autonómicas, sin mediar un estado de alarma que justifique la excepción o sin existir una ley orgánica que desarrolle el posible ámbito de injerencia en un derecho fundamental en concreto. Un problema añadido es que este tipo de medidas restrictivas estarían sometidas al control de la jurisdicción contencioso-administrativa ${ }^{13}$, no al Tribunal Constitucional en primer orden, lo que provoca cierta contradicción respecto a la naturaleza de la limitación de derechos. Esto se debe a que la limitación se produce con carácter general, es decir, no para un grupo específico y determinado de personas ${ }^{14}$.

Finalmente se ha optado por decretar un nuevo estado de alarma que ampare la limitación del derecho a la libertad circulatoria estableciendo una restricción horaria para la movilidad de las personas ${ }^{15}$, conjugándolo con una amplia discrecionalidad en la adopción de medidas particulares por parte de las autonomías a partir de la legislación ordinaria citada supra. Es ésta una fórmula

11 BOE núm. 102 de 29 de abril de 1986.

12 BOE núm. 240 de 5 de octubre de 2011.

13 Art. 10.8 de la Ley 29/1998, de 13 de julio, reguladora de la Jurisdicción Contencioso-administrativa (en lo siguiente, Ley 29/1998), BOE núm. 167 de 14 de julio de 1998.

$14 C f r$. Tribunal Superior de Justicia de Madrid (Sala de lo contencioso-administrativo, Sección $8^{\text {a). }}$ ). Auto núm. 128/2020 de 8 de octubre de 2020.

15 Real Decreto 926/2020, de 25 de octubre, por el que se declara el estado de alarma para contener la propagación de infecciones causadas por el SARS-CoV-2, BOE núm. 282 de 25 de octubre de 2020. Y, Real Decreto 956/2020, de 3 de noviembre, por el que se prorroga el estado de alarma declarado por el Real Decreto 926/2020, de 25 de octubre, por el que se declara el estado de alarma para contener la propagación de infecciones causadas por el SARS-CoV-2, BOE núm. 291 de 4 de noviembre de 2020. 
híbrida que no deja de ser cuestionable desde una perspectiva constitucional, pero cuyo sustrato teórico escapa de las pretensiones de este trabajo.

Ante todas estas incertezas jurídicas, el principio de proporcionalidad ${ }^{16}$ puede resultar muy útil en un doble sentido:

En primer lugar, como principio integrador del derecho para cubrir las carencias e insuficiencias legales, instaurando un método ordenado con el que descartar las restricciones excesivas y no necesarias para el fin que se pretende.

Y, en segundo lugar, como método interpretativo para fijar los "límites" de la acción gubernativa limitadora de derechos, lo que permite determinar la conveniencia y legitimidad de la medida restrictiva. La fórmula estructurada y el orden lógico del principio contribuyen además a mitigar la discrecionalidad en la adopción de las restricciones.

Analizar la pertinencia de las medidas limitativas de derechos en clave de proporcionalidad implica sentar algunas premisas sobre estas incertidumbres constitucionales. De lo contrario, resultaría imposible construir una fórmula alternativa de control a la injerencia de los poderes públicos en el disfrute de los derechos fundamentales a partir de las posibilidades de la proporcionalidad. Así las cosas y en respuesta a los problemas constitucionales aludidos, intentaremos arrojar algo de luz con el propósito de sentar el punto de partida de este análisis jurídico.

\section{ESTADO DE ALARMA Y LIMITACIÓN DE DERECHOS}

En lo que respecta a la primera cuestión, esto es, en lo referente a la pregunta de si las limitaciones derivadas de la declaración del estado de alarma eran las adecuadas a esta fórmula de derecho extraordinario o si, por el contrario, nos

16 En cuanto a métodojurídico estructurado de proporcionalidad formulado por la jurisprudencia y doctrina alemana e incorporado a la doctrina de nuestro Tribunal Constitucional. Vid. sobre el origen y la estructura del principio: Carlos Bernal Pulido, El principio de proporcionalidad y los derechos fundamentales (Madrid: Centro de Estudios Políticos y Constitucionales, 2005), 616-688. La incorporación del test alemán a la doctrina del Tribunal Constitucional se realizó a partir de la STC 66/1995: Tribunal Constitucional (Sala Segunda). Sentencia núm. 66/1995, de 8 de mayo, FJ 5. 
encontrábamos más bien ante una suspensión general de derechos y libertades más propia de la figura del estado de excepción, interesa delimitar el supuesto de hecho que habilita al gobierno para activar una fórmula de derecho excepcional (a) y precisar las nociones de "limitación" y "suspensión” de derechos (b).

a) El artículo 4 de la LO 4/1981 establece los presupuestos de hecho de "alteración de la normalidad" para los cuales está prevista como consecuencia jurídica, la posible declaración por parte del Gobierno del estado de alarma, en todo o en parte del territorio nacional. En concreto, el apartado b) del art. 4 señala como presupuesto: "Crisis sanitarias, tales como epidemias y situaciones de contaminación graves." Es un hecho que la incidencia del virus COVID-19 dentro y fuera de nuestras fronteras es una crisis sanitaria grave que encaja de lleno en el apartado b) del precepto.

Por su parte, el art. 13.1 de la citada LO 4/1981 establece que:

"Cuando el libre ejercicio de los derechos y libertades de los ciudadanos, el normal funcionamiento de las instituciones democráticas, el de los servicios públicos esenciales para la comunidad, o cualquier otro aspecto del orden público, resulten tan gravemente alterados que el ejercicio de las potestades ordinarias fuera insuficiente para restablecerlo y mantenerlo, el Gobierno, de acuerdo con el apartado tres del artículo ciento dieciséis de la Constitución, podrá solicitar del Congreso de los Diputados autorización para declarar el estado de excepción”.

La declaración del estado de excepción en este punto parte del supuesto de hecho de una grave alteración del orden público. El concepto de orden público es un concepto jurídicamente indeterminado ${ }^{17}$ que se colma de contenido en el caso concreto como título habilitante para determinadas intervenciones administrativas. El Tribunal Constitucional se ha cuidado de precisar la interpretación del concepto "orden público" como elemento limitante de los derechos fundamentales y justificador de intervenciones gubernativas:

17 Marisa Iglesias Vila, "Los conceptos esencialmente controvertidos en la interpretación constitucional", Doxa. Cuadernos de filosofía del derecho 23 (2000): 77-104. 
"El orden público no puede ser interpretado en el sentido de una cláusula preventiva frente a eventuales riesgos, porque en tal caso ella misma se convierte en el mayor peligro cierto para el ejercicio de ese derecho de libertad. (...), sólo cuando se ha acreditado en sede judicial la existencia de un peligro cierto para "la seguridad, la salud y la moralidad pública, tal como han de ser entendidos en una sociedad democrática, es pertinente invocar el orden público como límite (...)" 18 .

El Tribunal Constitucional, por tanto, ha indicado cómo debe interpretarse la cláusula del orden público "a la luz de los principios del estado social y democrático de derecho consagrado por la Constitución”, señalando que ha de estarse ante una grave perturbación de la seguridad, de la salud y de la moralidad pública, afectando a la integridad física y moral de las personas, así como a la de los bienes públicos y privados, y que, además, esa perturbación sea acreditada por una autoridad judicial. Sucede que sienta esta interpretación en sede de caso concreto, no a nivel general; sin embargo, el concepto coadyuva a determinar si la emergencia sanitaria generada por la pandemia ha supuesto esa grave alteración que justificaría una intervención generalizada de los derechos de las personas.

Es innegable que la salud pública consagrada en el art. 43 CE está afectada y que es el bien jurídico constitucional que, junto a la vida y a la integridad física de las personas (art. $15 \mathrm{CE}$ ), se pretende salvaguardar con el derecho de excepción. Asimismo, también es innegable que se da el presupuesto de hecho del estado de alarma (crisis sanitaria), aunque a priori y sin entrar en otras consideraciones sea posible construir teóricamente un argumento que abogue por una grave alteración del orden público en lo que a la salud y a la prestación de servicios sanitarios se refiere. En el momento en el que se decreta el estado de alarma no existía una vulneración de los derechos y libertades ciudadanas ni se había alterado el normal funcionamiento de las instituciones democráticas ${ }^{19}$. Podría

18 Tribunal Constitucional (Pleno). Sentencia 46/2001, de 15 de febrero, FJ 11, párrafo $3^{\circ}$.

19 Cfr. Vicente Álvarez García, "El coronavirus (COVID-19): respuestas jurídicas frente a una situación de emergencia sanitaria", El Cronista del Estado Social y Democrático de Derecho 86-87 (2020): 15. 
cuestionarse si la prestación de servicios esenciales sanitarios se encontraba ya en este momento inicial tan desbordada que hubiera podido aconsejar, dada la gravedad de la situación, otro tipo de derecho de excepción desde la perspectiva del presupuesto habilitante ${ }^{20}$. Sin embargo, la premisa de intervención más favorable y menos restrictiva de los derechos fundamentales que reiterativamente ha mantenido el Tribunal Constitucional ${ }^{21}$ apoya la tesis de considerar la adopción de un estado de alarma como más adecuada que un estado de excepción, sobre todo por la literalidad del supuesto de hecho y porque en marzo de 2020, cuando se decreta el estado de alarma no se podía constatar una perturbación grave del orden público más allá de la existencia de una crisis sanitaria sin precedentes ${ }^{22}$.

Este argumento se sustenta también en las posturas doctrinales que han querido ver en la regulación de los estados de alarma, excepción y sitio cierta relación de gradualidad que se intensifica en la medida en que se pasa de un estado a otro y se constatan las situaciones cualitativas para las que están previstos y el nivel de restricción de derechos de las medidas contempladas para contrarrestarlas ${ }^{23}$. En esta línea, el estado de alarma se configuraría como el derecho excepcional de menor escala para afrontar situaciones extrañas a la normalidad jurídica de carácter natural (catástrofes, crisis sanitarias, desabastecimientos y paralización de servicios públicos esenciales ligado a alguno de los

20 Así lo ha entendido Francisco Javier Díaz Revorio, “A vueltas con la suspensión de los derechos fundamentales", Almacén de Derecho, 9 de abril de 2020, acceso el 18 de diciembre de 2020, https://almacendederecho.org/a-vueltas-con-la-suspension-de-los-derechos-fundamentales

En descuerdo con esta postura, cfr. Pedro Cruz Villalón, "La Constitución bajo el estado de alarma", El País, 17 de abril de 2020, acceso el 18 de diciembre de 2020, https://elpais.com/elpais/2020/04/16/ opinion/1587025782_7336,59.html

En la misma línea, Miguel Ángel Presno Linera, "Estado de alarma y sociedad del riesgo global”, en Las respuestas del derecho a las crisis de salud pública, dir. por Elena Atienza Macías y Juan Francisco Rodríguez Ayuso (Madrid: Dykinson, 2020), 24-25.

21 Tribunal Constitucional (Sala Primera). Sentencia núm. 177/2002, de 14 de octubre, FJ 3; Tribunal Constitucional (Sala Primera). Sentencia núm. 40/2003, de 27 de febrero, FJ 2; y, más recientemente, Tribunal Constitucional (Pleno). Sentencia núm. 76/2019, de 22 de mayo, FJ 5, y las allí citadas.

22 La mayor parte de la doctrina ha entendido que no concurre el presupuesto habilitante de la perturbación grave del orden público. Por todos, Miguel Ángel Presno Linera, "Fortalezas...”, 41-42.

23 José Manuel Serrano Alberca, “Comentario al artículo 116”, en Comentarios a la Constitución, dir. por Fernando Garrido Falla (Madrid: Civitas, 2001), 1776. 
tres supuestos anteriores) al margen de los desórdenes políticos ${ }^{24}$ y con mínima injerencia en los derechos de las personas ${ }^{25}$. Esto no significa que este tipo de derecho extraordinario no sirva también para resolver situaciones de alteración de la paz social "que perturben el normal desenvolvimiento de la vida social del país”26. De hecho, según un sector doctrinal mayoritario, el estado de alarma es una herramienta útil y versátil ante las emergencias naturales y crisis sanitarias (pandemia de la COVID-19) ${ }^{27}$, pero también para la resolución de "determinados conflictos sociales que no requieran la suspensión generalizada de derechos" (caso del estado de alarma decretado en diciembre de 2010 para restablecer el tránsito aéreo ante los desacuerdos del Ministerio de Fomento con los controladores aéreos de AENA) ${ }^{28}$.

Así las cosas, en principio, la emergencia sanitaria por la COVID-19 encaja de lleno en el presupuesto de hecho del art. 4.b) de la LO 4/1981, siendo constitutiva de una declaración de estado de alarma, que conlleva una limitación de derechos prevista en los arts. 11 y 12 de la LO 4/1981 y que se pueden resumir en la limitación de la libertad circulatoria a través de un confinamiento excepcionado para adquirir alimentos, medicinas y productos de primera necesidad, asistencia a centros sanitarios, desplazamiento al lugar de trabajo y a la residencia habitual, asistir a las personas mayores, discapacitadas, menores de edad o dependientes o con cualquier otro tipo de vulnerabilidad, desplazamiento a

$24 \mathrm{Al}$ respecto, vid. los debates parlamentarios de aprobación de la LO 4/1981, donde se desvincula al estado de alarma de los conflictos relativos al orden público, en un intento de despolitizar esta figura de derecho excepcional. Boletín Oficial de las Cortes Generales, Congreso de los Diputados no 73 -I de 14 de abril de 1981, 28-29. Y, a mayor abundamiento: Fernando Santaolalla López, "Crónica parlamentaria", Revista española de Derecho Constitucional 2 (1981): 264-281. Y, Pedro Cruz Villalón, "El nuevo derecho de excepción (LO 4/1981, de 1 de junio)", Revista Española de Derecho Constitucional 2 (1981): 93-128. 25 Antonio María García Cuadrado, El ordenamiento constitucional (un enfoque histórico y formal de la teoría de la Constitución y de las fuentes del derecho) (San Vicente de Raspeig: Club universitario, 2002): 189-192.

26 Goig Martínez, Juan Manuel, "La defensa política de la Constitución. Constitución y estados excepcionales (II). Un estudio de derecho constitucional comparado", Revista de Derecho UNED 4 (2009): 225. Carlos Garrido López, "La naturaleza bifronte del estado de alarma y el dilema limitación-suspensión de derechos", Teoría y Realidad Constitucional 46 (2020): 378-383.

27 Así lo ha declarado el Tribunal Constitucional (Sala Primera). Auto núm. 40/2020, de 30 de abril, FJ 4 .

28 Real Decreto 1673/2010, de 4 de diciembre, por el que se declara el estado de alarma para la normalización del servicio público esencial del transporte aéreo, BOE núm. 295 de 4 de diciembre de 2010. Cfr. Carlos Garrido López, "La naturaleza bifronte...", 381 y 391-393. 
entidades financieras y de seguros, o cualquier otro desplazamiento de análoga naturaleza o por causa de fuerza mayor; prohibición de actividades grupales; cierre de fronteras; e, intervención de material sanitario de protección frente al virus.

No han faltado quienes han visto en estas excepciones una restricción absoluta del derecho a la libertad circulatoria alegando que nos encontrábamos ante un "estado de excepción encubierto" 29.

b) La problemática de la suspensión general o restricción absoluta de derechos frente a su limitación justificada trae causa de un profundo debate doctrinal relativo a los límites de los derechos fundamentales prolijamente tratado en la academia desde los inicios del constitucionalismo30. No obstante, si nos circunscribimos a la discusión que se ha generado en el contexto del estado de alarma decretado en marzo de 2020 para afrontar la pandemia, la cuestión podría simplificarse en las particularidades concretas de las situaciones que se han producido.

Así, se ha cuestionado: primero, que la prohibición de movilidad fuese la norma general, mientras los condicionantes para su ejercicio constituían la excepción; de modo que se afectaba al núcleo esencial del derecho haciéndolo impracticable y no reconocible ${ }^{31}$. Segundo, que de forma tácita se impedían otros derechos conexos con la libertad de movimiento y con la libertad de empresa, como son la libertad religiosa y de culto, el derecho de reunión y manifestación, la huelga y el derecho de sufragio ${ }^{32}$.

29 Manuel Aragón Reyes, “Hay que...”. Y, Javier Albar García, "Estado de excepción encubierto”, El español, 18 de abril de 2020, acceso el 18 de diciembre de 2020, https://www.elespanol.com/opinion/tribunas/20200418/excepcion-encubierto/483321669_12.html

3o Cfr. Robert Alexy, Teoría de los derechos fundamentales, (Madrid: Centro de Estudios Políticos y Constitucionales, 1993), 267-380. Asimismo, cfr. Ignacio de Otto y Pardo, Derechos fundamentales y Constitución, (Madrid: Civitas, 1988), 95-170; Luis Prieto Sanchís, Justicia constitucional y derechos fundamentales, (Madrid, Trotta, 2003), 217-260; Peter Häberle, La garantía del contenido esencial de los derechos fundamentales, (Madrid: Dykinson, 2003), 33-69; Javier Jiménez Campos, Derechos fundamentales. Concepto y garantías, (Madrid: Trotta, 1999), 36-69.

31 La postura más ilustrativa es la de Francisco Javier Díaz Revorio, “A vueltas...”. Reflejando la problemática y algunas posturas doctrinales más, vid. Carlos Garrido López, "La naturaleza bifronte...”, 393-394. 32 Germán Manuel Teruel Lozano, "Control al Gobierno", El País, 8 de abril de 2020, acceso el 18 de diciembre de 2020, https://elpais.com/elpais/2020/04/o7/opinion/1586281172_163691.html 
Respecto a lo primero, la redacción del enunciado normativo en términos afirmativos o negativos es una cuestión semántica de relevancia, dado que influye en el grado de afectación del derecho y se escapa del encaje normativo previsto en la LO 4/1981. El art. 11 de la LO 4/1981 preceptúa que durante el estado de alarma se pueden "limitar la circulación o permanencia de personas o vehículos en horas y lugares determinados, o condicionarlas al cumplimiento de ciertos requisitos"; mientras que el art. 20 de la LO 4/1981, relativo al estado de excepción, estatuye que se podrá "prohibir la circulación de personas y vehículos en las horas y lugares que se determine”. De la literalidad de las normas se desprende que en el estado de alarma sólo cabe la "limitación", no la suspensión o prohibición general; ésta última es la injerencia de mayor gradación que se reserva al estado de excepción. Sin embargo, la redacción del art. 7 del Real Decreto 463/2020, mantenida por el resto de prórrogas, habla de una "prohibición general" con "excepciones" concretas sometidas a determinados "condicionantes”. Por tanto, la afectación del derecho parece más intensa e incisiva de lo que, en principio, está permitido normativamente para un estado de alarma. Según el profesor Francisco Javier Díaz Revorio esta intensidad hace impracticable el derecho y consecuentemente cabría el estado de excepción, o la adopción de medidas que materialmente no fueran una prohibición general del derecho de movilidad 33 . En sentido contrario, y justificando la incidencia en el contenido esencial, se manifiesta el profesor Lorenzo Cotino Hueso, para quien la incidencia está justificada y permite "niveles importantes de movilidad y circulación”34.

Respecto a lo segundo, lo cierto es que los derechos conexos nunca han estado limitados de forma directa ni material y cabía su ejercicio en la medida en que se pudiera justificar su pertinencia y el aseguramiento de su realización en condiciones respetuosas con las medidas sanitarias y preventivas. Muestra de

33 Francisco Javier Díaz Revorio, “A vueltas...”. En la misma línea, Manuel Aragón Reyes, "Hay que...”. 34 Lorenzo Cotino Hueso, "Confinamientos, libertad de circulación y personal, prohibición de reuniones y actividades y otras restricciones de derechos por la pandemia del Coronavirus", Diario La Ley - Wolters Kluwer, 30 de marzo de 2020, acceso el 18 de diciembre de 2020, https://diariolaley.laleynext.es/dll/2020/o4/o6/confinamientos-libertad-de-circulacion-y-personal-prohibicion-de-reuniones-y-actividades-y-otras-restricciones-de-derechos-por-la-pandemia-del-coronavirus 
ello son el sentido permisivo o denegatorio de diversos Tribunales Superiores de Justicia ante la celebración de manifestaciones el día 1 de mayo de 202035 .

La doctrina mayoritaria considera que un derecho está suspendido o restringido de forma absoluta cuando la norma que lo regula pierde toda su vigencia y eficacia, es decir, cuando el derecho deja de existir y su regulación ordinaria deviene inaplicable ${ }^{36}$. La inexistencia del derecho implica la ausencia de garantías y mecanismos de protección y tutela durante la suspensión y, como se constata en las diversas resoluciones judiciales de los Tribunales Superiores de Justicia de las Comunidades Autónomas y del Tribunal Constitucional37, en ningún momento durante la vigencia del estado de alarma han cedido este tipo de garantías.

El hecho de que la limitación se imponga a través de una norma gubernamental con rango de ley, como es un Decreto Ley y no a través de una ley orgánica es otro cuestionamiento que arguyen quienes abogan por el estado de

35 En sentido permisivo, vid. Tribunal Superior de Justicia de Aragón (Sala de lo contencioso-administrativo, Sección $1^{\mathrm{a}}$ ). Sentencia núm. 151/2020, de 30 de abril de 2020, FFJJ 4 y 5: "La regla general es favorecer la celebración de manifestaciones, que sólo podrán prohibirse cuando, "previa ponderación y juicio de proporcionalidad, concurren datos y circunstancias que permiten su limitación, en garantía de un interés constitucional o público superior”. Por ello, para prohibirla habrá de existir una motivación jurídica, previo análisis de aquellos elementos de hecho que permitan justificar o bien su prohibición o bien la posibilidad de celebrarla atendiendo a unos requisitos". En la misma línea: Tribunal Superior de Justicia de Madrid (Sala de lo contencioso-administrativo, Sección 10 a). Sentencia núm. 214/2020, de 21 de mayo; y, Tribunal Superior de Justicia de Navarra (Sala de lo contencioso-administrativo, Sección $1^{\text {a }}$ ). Sentencia núm. 69/2020, de 30 de abril. En sentido contrario, confirmando la negativa a celebrar una manifestación debido al no aseguramiento de las medidas sanitarias y de prevención: Tribunal Superior de Justicia de Galicia (Sala de lo contencioso-administrativo, Sección 1 ${ }^{a}$ ). Sentencia núm. 136/2020, de 28 de abril de 2020; y, Tribunal Superior de Justicia de Extremadura (Sala de lo contencioso-administrativo, Sección $1^{\mathrm{a}}$ ). Sentencia núm. 118/2020, de 12 de mayo de 2020.

36 Cfr. Juan Alfonso Santamaría Pastor, "Notas sobre el ejercicio de las potestades normativas en tiempos de pandemia”, en Derecho Público (durante el estado de alarma y más allá), dir. por David Blanquer Criado (Valencia: Tirant lo Blanch, 2020): 207-240.

37 Como muestra, vid. las resoluciones de los Tribunales Superiores de Justica cit. supra; también: Tribunal Constitucional (Sala Primera). Auto núm. 40/2020, de 30 de abril; y, el recurso de inconstitucionalidad núm. 2054/2020, interpuesto por el grupo parlamentario Vox, contra los artículos 7, 9, 10 y 11 del Real Decreto 463/2020, de 14 de marzo, por el que se declara el estado de alarma para la gestión de la situación de crisis ocasionada por el COVID-19; el Real Decreto 465/2020, de 17 de marzo; el Real Decreto 476/2020, de 27 de marzo; el Real Decreto 487/2020, de 10 de abril; el Real Decreto 492/2020, de 24 de abril; y la Orden SND/298/2020, de 29 de marzo, por la que se establecen medidas excepcionales en relación con los velatorios y ceremonias fúnebres para limitar la propagación y el contagio por el COVID-19, BOE núm. 128 de 8 de mayo de 2020, pendiente de resolución. 
excepción y hablan de la suspensión general de derechos ${ }^{3}$. Se trata de un argumento vacío pues las limitaciones establecidas en el Real Decreto 463/2020 encuentran su previsión legal en los arts. 11 y 12 de la LO 4/1981. Podría discutirse sobre si tales previsiones son lo suficientemente específicas o previsoras o si necesitan de un desarrollo legislativo, pero no cabría cuestionar, al menos desde una perspectiva jurídica, la formalidad legal de las previsiones limitativas de los derechos en los decretos de alarma y el respeto a la reserva de ley orgánica establecida por la Constitución para el desarrollo y límite de estos derechos. Es el propio texto constitucional el que prevé la excepcionalidad del estado de alarma y el hecho de que una ley orgánica lo desarrolle estableciendo las limitaciones oportunas dentro del marco establecido en los arts. 14 a 29, 55 y $116 \mathrm{CE}$.

Por último, conviene subrayar que la mayor parte de la doctrina ha considerado que las interferencias en el derecho a la movilidad de las personas y la libertad de empresa estaban justificadas en el propósito de preservación de la salud pública y en la salvaguarda de la vida de las personas, bienes constitucionalmente protegidos ${ }^{39}$; que han sido proporcionadas a dicho fin, siendo necesarias y adecuadas para su cumplimiento ${ }^{40} ; \mathrm{y}$, que, además, no se ha sacrificado el núcleo esencial del derecho sino sólo su halo de ejercicio durante un tiempo determinado que, dada la magnitud e incertidumbre de la emergencia, se alargó periódicamente a través de las sucesivas prórrogas.

\section{LA NECESIDAD DE UN DERECHO DE EXCEPCIÓN PARA LIMITAR DE- RECHOS FUNDAMENTALES}

El uso de la legislación ordinaria para limitar la libertad de movimiento de las personas sin amparo en alguna fórmula de derecho excepcional es otro de los debates constitucionales que copan la actualidad del escenario jurídico y

38 De nuevo, vid. Francisco Javier Díaz Revorio, “A vueltas...”. Reflejando la problemática y algunas posturas doctrinales más, vid. Carlos Garrido López, "La naturaleza bifronte...”, 394.

39 Carlos Garrido López, "La naturaleza bifronte...", 396-398, así como la doctrina allí citada. Cfr. Tribunal Constitucional (Pleno). Sentencia núm. 83/2016, de 28 de abril, FJ 8.

40 Lorenzo Cotino Hueso, “Confinamientos, libertad...”. 
político. A esto hay que sumar la particularidad de la organización territorial española en Comunidades Autónomas, con un reparto competencial que supera las previsiones del constituyente y del legislador en el momento de aprobación de la normativa de excepción en nuestro estado ${ }^{41}$ y que pueden arrojar diferencias en la regulación jurídica específica de cada territorio42. Estas diferencias, fruto de la heterogeneidad de la normativa autonómica y de la propia situación fáctica de los distintos territorios, pueden ser resolutivas por adecuadas y necesarias a coyunturas concretas de la pandemia, pero pueden también entrañar cierta descoordinación o incluso incidir de forma no justificada y no garantista en los derechos de las personas.

Según el art. 3 de la Ley 3/1986:

"Con el fin de controlar las enfermedades transmisibles, la autoridad sanitaria, además de realizar las acciones preventivas generales, podrá adoptar las medidas oportunas para el control de los enfermos, de las personas que estén o hayan estado en contacto con los mismos y del medio ambiente inmediato, así como las que se consideren necesarias en caso de riesgo de carácter transmisible".

Dado que la previsión normativa del art. 3 de la Ley 3/1986 estaba orquestada para medidas específicas que afectasen a personas concretas (caso en el que resulta más sencillo justificar la intervención para proteger el bien común de la vida, la integridad física y la salud) la utilización del citado precepto para la adopción de medidas preventivas que afecten a los derechos de las personas de un modo generalizado ha sido muy cuestionada. Es por ello que se ha ampliado la competencia del poder judicial para ratificar este tipo de medidas. Así las cosas, este artículo debe interpretarse en conjunción con el art. 10.8 de la Ley 29/199843, que refiriendo las competencias de las salas de lo contencioso-administrativo de los Tribunales Superiores de Justicia, reza del siguiente tenor:

41 Cfr. Francisco Velasco Caballero, "Estado de alarma y distribución territorial del poder", El Cronista del Estado Social y Democrático de Derecho 86-87 (2020): 78-87.

42 Por todas, vid. Tribunal Constitucional (Pleno). Sentencia núm. 37/1981, de 16 de noviembre, FJ 2.

$43 \mathrm{El}$ apartado $8^{\circ}$ fue introducido en el art. 10 de la Ley 29/1998 como una competencia más de las Salas de lo contencioso-administrativo de los Tribunales Superiores de Justicia por la Ley 3/2020, de 18 de septiembre, de medidas procesales y organizativas para hacer frente al COVID-19 en el ámbito de la 
“Conocerán de la autorización o ratificación judicial de las medidas adoptadas con arreglo a la legislación sanitaria que las autoridades sanitarias de ámbito distinto al estatal consideren urgentes y necesarias para la salud pública e impliquen la limitación o restricción de derechos fundamentales cuando sus destinatarios no estén identificados individualmente”.

Es decir, cuando una autoridad autonómica adopte medidas preventivas y de control sanitario que afecten a los derechos fundamentales de las personas dentro de su ámbito territorial, ya sea en todo o en parte, tales medidas deberán ser ratificadas por la autoridad judicial44.

A pesar de que esta posibilidad pueda ser muy funcional para dar una respuesta rápida y ajustada a las dispares situaciones que puedan producirse en los distintos territorios, no deja de preocupar en la academia que las previsiones que se adopten bajo el amparo de esta legislación ordinaria puedan ser excesivas y desproporcionadas45. Parece mucho más garantista en un estado de derecho asegurar de alguna forma la necesidad y durabilidad de las medidas adoptadas, la proporcionalidad de la limitación del derecho fundamental afectado y, por supuesto, lo extraordinario de la injerencia de los poderes públicos en los derechos de las personas. Para ello es imprescindible establecer fórmulas de control parlamentario garantista, además de judiciales, que avalen la limitación de derechos en su justa medida. En consonancia con las opciones legislativas del

Administración de Justicia, BOE núm. 250 de 19 de septiembre de 2020. La constitucionalidad de este precepto se ha cuestionado ante el Tribunal Constitucional por posible conculcación de los arts. 106, 117.3 y 4 CE, cfr. Tribunal Superior de Justicia de Aragón Sala de lo contencioso-administrativo, Sección $1^{\text {a }}$ ). Auto del procedimiento ordinario núm. 332/2020, de 3 de diciembre de 2020.

44 Así, como muestra, las han ratificado Galicia: Tribunal Superior de Justicia de Galicia (Sala de lo contencioso-administrativo, Sección $3^{\mathrm{a}}$ ). Auto núm. 83/2020, de 23 de septiembre de 2020; Andalucía: Tribunal Superior de Justicia de Andalucía (Sala de lo contencioso-administrativo, Sección 1a). Auto núm. 220/2020, de 2 de octubre de 2020; Extremadura: Tribunal Superior de Justicia de Extremadura (Sala de lo contencioso-administrativo, Sección $1^{\text {a }}$ ). Auto núm. 101/2020, de 5 de octubre de 2020; Comunidad Valenciana: Tribunal Superior de Justicia de la Comunidad Valenciana (Sala de lo contencioso-administrativo, Sección $4^{\mathrm{a}}$ ). Auto núm. 130/2020, de 6 de octubre de 2020, y Auto núm. 142/2020, de 27 de octubre de 2020; Castilla y León: Tribunal Superior de Justicia de Castilla y León (Sala de lo contenciosoadministrativo, Sección $1^{\text {a }}$ ). Auto núm. 297/2020, de 6 de noviembre de 2020. En sentido contrario, Aragón: Tribunal Superior de Justicia de Aragón (Sala de lo contencioso-administrativo, Sección $1^{\circ}$ ). Auto núm. 87/2020, de 5 de octubre de 2020.

45 Francisco Velasco Caballero, "Sobre la ratificación judicial de las medidas sanitarias contra el COVID19”, Revista del Consejo General de la Abogacía Española 123 (2020): 10-12. Miguel Ángel Presno Linera, "Fortalezas...", 48-52. 
momento, parece que lo más adecuado es adoptar una fórmula de derecho excepcional, como es el estado de alarma. Al menos así se garantiza la excepcionalidad de las circunstancias que conllevan cierta intromisión o limitación de derechos fundamentales, así como de las potestades normativas del momento, las cuales son mucho más amplias que en un contexto de normalidad jurídica. No obstante, cuando la situación de excepción se alarga en el tiempo hasta transformarse en la "nueva normalidad" se corre el riesgo de convertir el derecho excepcional en el nuevo régimen normativo ordinario.

No olvidemos tampoco que el control de las disposiciones declarativas de los estados de alarma y excepción corresponde al Tribunal Constitucional, dado que los decretos que los declaran se consideran normas con rango de ley. Así lo ha manifestado expresamente el propio Órgano ${ }^{46}$. Este control sería un punto favorable para controlar la limitación de los derechos fundamentales durante la vigencia del estado de alarma, sino fuera porque el Tribunal Constitucional es excesivamente lento en resolver sobre dudas de constitucionalidad y es más que probable que su respuesta sobre la posible inconstitucionalidad de las limitaciones operadas llegue en un momento tan posterior, que ya no tenga una eficacia práctica, sino meramente teórica 47.

En cualquier caso, estas problemáticas jurídicas ponen de manifiesto la necesidad de una modificación del derecho de excepción en España que colme las insuficiencias y carencias normativas que se han revelado durante la aplicación del estado de alarma.

46 Tribunal Constitucional (Pleno). Sentencia núm. 83/2016, de 28 de abril, FJ 10.

47 A fecha de cierre de este artículo hace más de sietes meses que se interpuso el recurso de inconstitucionalidad núm. 2054/2020, citado supra, contra los artículos 7, 9, 10 y 11 del Real Decreto 463/2020, de 14 de marzo, por el que se declara el estado de alarma para la gestión de la situación de crisis ocasionada por el COVID-19; el Real Decreto 465/2020, de 17 de marzo; el Real Decreto 476/2020, de 27 de marzo; el Real Decreto 487/2020, de 10 de abril; el Real Decreto 492/2020, de 24 de abril; y la Orden $\mathrm{SND} / 298 / 2020$, de 29 de marzo, por la que se establecen medidas excepcionales en relación con los velatorios y ceremonias fúnebres para limitar la propagación y el contagio por el COVID-19, BOE núm. 128 de 8 de mayo de 2020, pendiente de resolución. 


\section{EL ESTADO SOCIAL Y DEMOCRÁTICO DE DERECHO: LOS DERECHOS FUNDAMENTALES COMO LÍMITE Y GARANTÍA FRENTE A LOS PODERES PÚBLICOS}

El estado social y democrático de derecho en el constitucionalismo contemporáneo y su organigrama institucional se caracterizan por unos rasgos definitorios esenciales, cuales son: de un lado, la especial rigidez de la Constitución y, de otro, el reconocimiento y garantía de un catálogo de derechos. Ambas características se constituyen en límites materiales para los poderes públicos, pero particularmente para el poder legislativo:

- La rigidez, en cuanto a que exige un agravamiento de la posible reforma de los preceptos constitucionales que recogen los derechos fundamentales (procedimiento agravado del art. $168 \mathrm{CE}$ ), haciéndolos indisponibles para el legislador 48 .

- Las garantías del catálogo de derechos, por su parte, en cuanto a que se concretan en la tutela jurisdiccional de aquellos mediante un procedimiento basado en los principios de preferencia y sumariedad y, en su caso, mediante la interposición de un recurso de amparo ante el Tribunal Constitucional, así como mediante el ejercicio de control de la constitucionalidad de las normas con rango de ley que efectúa el mismo órgano constitucional (artículos 53.2 y $161 \mathrm{CE})$.

Tanto la rigidez de la Constitución como el control de constitucionalidad de las leyes se combinan como mecanismos institucionales de protección de los derechos fundamentales del individuo y como límites materiales a los poderes del Estado. Asimismo, tanto el Ministerio Fiscal (art. 124.1 CE) como el Defensor del Pueblo (art. $54 \mathrm{CE}$ ) son instituciones encargadas en mayor o menor medida de la protección y salvaguarda de los derechos fundamentales.

48 Pedro de Vega García, "Comentario al Título X. De la reforma constitucional", en Constitución española. Edición comentada, dir. por Luis Sánchez Agesta et al., (Madrid: Centro de Estudios Constitucionales, 1979), 359-360. 
A estas garantías de tipo institucional es preciso añadir otras como la vinculación de los poderes públicos a los derechos fundamentales y libertades públicas reconocidas en el Capítulo Segundo del Título I de la CE y el necesario desarrollo legislativo por medio de ley orgánica en el pleno respeto al contenido esencial del derecho (art. 53.1 CE)49.

Los derechos fundamentales actúan como salvaguarda del estado democrático de derecho y como elemento de garantía del funcionamiento institucional del estado ${ }^{5}$. La Constitución como norma suprema del ordenamiento jurídico establece las reglas de ordenación del poder y de funcionamiento institucional en condiciones de normalidad, pero debe también prever un régimen normativo para supuestos de anormalidad ${ }^{51}$. Tanto en circunstancias ordinarias como excepcionales, el texto fundamental regula la ordenación del poder y garantiza los derechos y libertades de las personas como muro de contención para los excesos de poder de las autoridades. El régimen de protección de los derechos sólo puede alterarse en situaciones excepcionales debidamente justificadas como son el derecho de excepción del que venimos tratando. Así, el derecho de excepción, en el bien entendido propósito de restablecer el orden perdido en una situación extraordinaria52, debe respetar las mayorías parlamentarias y el principio democrático, así como la mínima intervención de los poderes del estado en el haz de facultades inherentes a los derechos fundamentales.

De conformidad a estos postulados del constitucionalismo contemporáneo, la CE de 1978 prevé la posibilidad de tres fórmulas de derecho de excepción (art. $116 \mathrm{CE}$ ) y remite a una ley orgánica el desarrollo de estos tres estadios (LO 4/1981). A su vez, prevé en el art. 55 CE que la suspensión general de determinados derechos sólo cabe en los supuestos de declaración de estado de excepción, no de estado de alarma. Para este último caso la LO 4/1981 establece en sus arts. 11 y 12 determinadas "limitaciones"; mientras que en los arts. 17 a 29 de la misma norma,

49 Ignacio de Otto y Pardo, Derechos...: 95-170.

50 Peter Häberle, La garantía..., 73-124.

51 Pedro Cruz Villalón, Estados excepcionales y suspensión de garantías (Madrid: Tecnos, 1984), 13-23.

52 Ana Aba Catoira, "El estado de alarma en España", Teoría y realidad constitucional 28 (2011): 315-316. 
dedicados al estado de excepción, alude a la "suspensión" y a la "prohibición general”.

La injerencia de los poderes públicos en la esfera de derechos y libertades de las personas sólo cabe de una forma motivada cuando existen razones fundadas en la protección de otros bienes constitucionalmente protegidos y siempre a través de una previsión legislativa que debe respetar los límites establecidos en la Constitución de forma expresa o tácita. El problema reside en conciliar el derecho de excepción no precisado en la CE o no suficientemente desarrollado en el aspecto material en la LO 4/1981, con el orden de poderes (estatales y autonómicos) y de garantías prestablecido en la CE. Es aquí donde el derecho de excepción, al revelarse incapaz de dar soluciones ciertas y previsibles jurídicamente para la restauración y preservación del orden normal (o, simplemente para justificar la durabilidad e intensidad de las medidas preventivas), hace aguas por todas partes y manifiesta su insuficiencia para afrontar una emergencia de este calado. Interesan sobre todo las incertidumbres relativas a la posible lesión de los derechos fundamentales por exceso en la intensidad y duración de las limitaciones previstas: primero, durante el estado de alarma; y, segundo, al amparo de la legislación ordinaria.

Ante esta situación y en espera del desarrollo legislativo adecuado, la proporcionalidad como mecanismo interpretativo del ordenamiento jurídico puede ofrecer una alternativa relevante a la hora de justificar la limitación de un derecho.

\section{EL PRINCIPIO DE PROPORCIONALIDAD}

\subsection{EL FUNDAMENTO CONSTITUCIONAL DE LA PROPORCIONALIDAD}

El principio de proporcionalidad prohíbe "todo sacrificio de la libertad inútil, innecesario o desproporcionado" 53 , justificando la legitimidad constitucional

53 Javier Barnés Vázquez, "El principio de proporcionalidad. Estudio preliminar", Revista Cuadernos de Derecho Público 5 (1998): 19. 
de su limitación en el caso de que ésta sea útil a un fin legítimo, necesaria y proporcionada. La proporcionalidad se puede definir como

“(...) el conjunto de criterios o herramientas que permiten medir y sopesar la licitud de todo género de límites normativos de las libertades, así como las de cualesquiera interpretaciones o aplicaciones de la legalidad que restrinjan su ejercicio, desde un concreto perfil o punto de mira: el de la inutilidad, innecesariedad y desequilibrio del sacrificio" 54 .

No es un principio constitucional, pues no se encuentra consagrado en el texto de la Constitución española ni en otros textos constitucionales de nuestro entorno55. El origen del principio de proporcionalidad está en la práctica jurisprudencial, y su formalización se produce en el ámbito de la dogmática jurídica, donde no faltan intentos de encontrar un fundamento constitucional para su aplicación. De un lado, están quienes defienden que se trata de una idea inherente a todo estado social y democrático de derecho (art. 1.1 CE) ${ }^{56}$, vinculada al ideal de justicia y consecuentemente operable como un principio inspirador en la aplicación de cualquier norma del ordenamiento jurídico. En esta línea está la tesis que sostiene que la proporcionalidad se basa en el valor superior de la justicia, pero en conexión con otros institutos jurídicos, como son la interdicción de la arbitrariedad (art. 9.3 CE) o la igualdad (arts. 1.1, 9.2 y 14 CE) 57. Esta teoría no está exenta de problemas. Incluso considerando a la desproporcionalidad como una especie o subtipo de arbitrariedad, la conexión entre estos institutos jurídicos no sería plenamente factible, ya que no todo acto desproporcionado tiene que ser necesariamente arbitrario o desigual. Del mismo modo, cabe la

54 Javier Barnés Vázquez, “El principio...”, 16.

55 Aharon Barak, Proporcionalidad. Los derechos fundamentales y sus restricciones (Lima: Palestra, 2017), 205-241.

56 Josefina Fernández Nieto, Principio de proporcionalidad y derechos fundamentales: una perspectiva desde el derecho común europeo (Madrid: Dykinson, 2008), 277-280; y, Daniel Sarmiento RamírezEscudero, El control de proporcionalidad en la actividad administrativa (Valencia: Tirant lo Blanc, 2004), 119.

57 Carlos Bernal Pulido, El principio..., 601-602. 
posibilidad de que un acto de los poderes públicos sea arbitrario por carecer de fin legítimo y justificación y, sin embargo sea proporcionado. $5^{8}$

Por último, el fundamento constitucional del principio de proporcionalidad puede incardinarse en la propia juridicidad de los derechos fundamentales. Esta fundamentación del principio de proporcionalidad casa perfectamente con la consideración de la proporcionalidad como método interpretativo de derechos fundamentales y se muestra como la más aconsejable por ser la que menos problemas implica.59 Se vincula con la protección que el artículo 53.1 CE dispensa al contenido esencial de los derechos fundamentales. Se entiende que toda injerencia en los derechos fundamentales que afecte a su contenido esencial es una medida desproporcionada; a sensu contrario, toda medida proporcionada respetará siempre el contenido esencial de un derecho fundamental. ${ }^{60}$ En la misma línea argumentativa, las medidas restrictivas de derechos fundamentales y desproporcionadas, serán lesivas de la dignidad humana, con lo cual la proporcionalidad encuentra también su sustento en el artículo 10.1 del texto fundamental, erigiéndose en "fundamento del orden público y de la paz social"; y, en el apartado segundo del mismo precepto, si tenemos en cuenta la consideración en el derecho internacional europeo de la proporcionalidad como principio general del ordenamiento. ${ }^{61}$ En este sentido, la interpretación conforme a los pactos y convenios internacionales suscritos por España que recogen el principio de proporcionalidad sirve para defender su fundamento constitucional.

La proporcionalidad puede también encontrar su sustento constitucional como método interpretativo de derechos fundamentales en la conexión que presenta con algunos de ellos. Así, por ejemplo, con el art. 17 CE (libertad personal) guarda una relación respecto a la proporcionalidad de las medidas cautelares en

58 Tribunal Constitucional (Pleno). Sentencia núm. 108/1986, de 29 de julio, FJ 18; Tribunal Constitucional (Pleno). Sentencia núm. 65/1990, de 5 de abril, FJ 6; y, Tribunal Constitucional (Pleno). Sentencia núm. 142/1993, de 22 de abril, FJ 9.

59 Carlos Bernal Pulido, El principio..., 597-60o. Cfr. Robert Alexy, Teoría..., 111-115; y, 135-138.

60 Tribunal Constitucional (Sala Primera). Sentencia núm. 50/1995, de 23 de febrero, FJ 7.

61 Se reconoce como principio comunitario desde las primeras resoluciones del Tribunal de Justicia de las Comunidades Europeas; sirva de ejemplo, por todas, vid. Tribunal de Justicia de la Unión Europea. Sentencia de 29 de noviembre de 1956, Fédération Charbonnière de Belgique, asunto 8/55. 
el proceso penal62. En sintonía con esta fundamentación existiría también interrelación con la libertad como valor superior del ordenamiento, y como principio inspirador, al ser la libertad un derecho en general inherente a la dignidad humana que conecta con los derechos específicos de las personas, haciendo posible su realización.

En definitiva, de lo expuesto podemos concluir que la solución más acertada es la fundamentación del principio de proporcionalidad en la protección que el artículo 53.1 CE brinda a los derechos fundamentales, en el sentido de que es un criterio hermenéutico y delimitador necesario para determinar el contenido esencial y definitivo de los derechos fundamentales. A esta fundamentación habría que añadir con carácter complementario una interpretación conjunta de los artículos 1.1, 9.3 y $10 \mathrm{CE}$, donde se proclaman las valores y presupuestos que subyacen en la proporcionalidad: libertad, justicia, igualdad, dignidad, legalidad e interdicción de la arbitrariedad de los poderes públicos.

Con base en este fundamento constitucional, resulta sencillo admitir la naturaleza o función del principio como "límite de los límites de los derechos fundamentales".

6.2. LA OPERATIVIDAD DE LA PROPORCIONALIDAD COMO "LÍMITE DE LÍMITE DE LOS DERECHOS FUNDAMENTALES"

La expresión "límite de los límites de los derechos fundamentales" comienza a utilizarse a partir de una conferencia sobre los límites de los derechos fundamentales pronunciada por el académico Karl August Betterman en Berlín en $1964^{63}$. Esta denominación pronto se utilizó para designar el conjunto de herramientas que acotaban el ámbito de injerencia de los poderes públicos en los derechos y libertades de los ciudadanos y ciudadanas, o, lo que es lo mismo establecían un límite a las competencias de los poderes públicos para no interferir

62 Hernán Fuentes Cubillos, "El principio de proporcionalidad en Derecho Penal. Algunas consideraciones acerca de su concretización en el ámbito de la individualización de la pena", Ius et praxis 14, 2 (2008): $15-42$.

63 Carlos Bernal Pulido, El principio..., 520. 
en el contenido de los derechos fundamentales. El propio autor considera como "límite de los límites de los derechos fundamentales" al contenido esencial y a la propia dignidad humana.

Otros autores han contribuido a fijar esta función del principio de proporcionalidad. Entre ellos, Winfried Kluth, para quien la "prohibición de exceso" es un "límite de límites" que "ha contribuido a fijar la proporcionalidad de las leyes" ${ }^{64}$. Por su parte, Mariano Bacigalupo Saggese considera que la proporcionalidad actúa como límite junto con la doctrina del postulado esencial de los derechos. ${ }^{65} \mathrm{El}$ profesor Manuel Medina Guerrero considera que la proporcionalidad es un "límite de límites" junto con el contenido esencial a las injerencias legislativas, pero distinguiendo esta naturaleza jurídica de la dimensión de criterio hermenéutico que ostenta el principio de proporcionalidad en la interpretación de los derechos fundamentales. ${ }^{66} \mathrm{Y}$, por último, Luis Aguiar de Luque, incluye la proporcionalidad en el catálogo de límites de las facultades de los poderes públicos, pero no sólo junto al contenido esencial, sino que se refiere también a otras técnicas de control. ${ }^{67}$

El Tribunal Constitucional también ha apoyado esta consideración de la proporcionalidad como línea roja para la limitación de los derechos fundamentales ${ }^{68}$, por lo que no cabe duda de esta funcionalidad del principio en la resolución de las dudas interpretativas referentes a la limitación y conflictos entre derechos fundamentales.

La ventaja inherente a esta configuración del principio de proporcionalidad reside en cuestionar la legitimidad de las actuaciones de los poderes públicos y

64 Winfried Kluth, "Prohibición de exceso y principio de proporcionalidad en Derecho alemán”, Revista Cuadernos de Derecho Público 5 (1998): 223.

65 Mariano Bacigalupo Saggese, "La aplicación de la doctrina de los límites inmanentes a los derechos fundamentales sometidos a reserva de limitación legal”, Revista Española de Derecho Constitucional 38 (1993): 297-315.

66 Manuel Medina Guerrero, "El principio de proporcionalidad y el legislador de los derechos fundamentales", Cuadernos de Derecho Público 5 (1998): 121. A mayor abundamiento, cfr. Manuel Medina Guerrero, La vinculación legislativa del legislador a los derechos fundamentales (Madrid: McGraw Hill, 1997).

67 Luis Aguiar Luque, "Los límites de los derechos fundamentales", Revista del Centro de Estudios Constitucionales 14 (1993), 9-34.

68 Tribunal Constitucional (Pleno). Sentencia núm. 84/2013, de 11 de abril, FJ 6. 
poner de relieve la conexión existente entre las competencias legislativas y jurisdiccionales y la proporcionalidad. La nota esencial de semejante caracterización es la relevancia de la proporcionalidad como técnica de control de la constitucionalidad en las intervenciones legislativas que afecten al ámbito de protección de los derechos fundamentales. El inconveniente radica en que, en el discurrir lógico de este razonamiento, se pueda llegar a pensar que el principio de proporcionalidad opera sólo como mecanismo de resolución interpretativa en los casos que llegan al Tribunal Constitucional.

En los últimos años la exigencia de proporcionalidad se ha incorporado en diversas leyes, formando parte de la exposición de motivos de la ley e incluso de su articulado. De hecho, aparece recogida en los diversos decretos que han declarado y prorrogado el estado de alarma durante la emergencia sanitaria como justificación a la exigencia del art. 1.2 de la LO 4/1981. Lo que proponemos en este trabajo para colmar las insuficiencias del derecho de excepción es el uso de la proporcionalidad como principio integrador del derecho, es decir, como alternativa para justificar no sólo la aplicación de las medidas restrictivas de los derechos fundamentales, sino también su adopción. No obstante, esto no significa que no se abogue por una actualización del derecho de excepción en España que permita dar respuestas ciertas y previsibles desde una perspectiva jurídica.

\section{APORTES DE LA PROPORCIONALIDAD EN LA ADOPCIÓN DE MEDIDAS RESTRICTIVAS DE DERECHOS}

El art. 1.2 de la LO 4/1981 señala que:

"Las medidas a adoptar en los estados de alarma, excepción y sitio, así como la duración de los mismos, serán en cualquier caso las estrictamente indispensables para asegurar el restablecimiento de la normalidad. Su aplicación se realizará de forma proporcionada a las circunstancias”.

Es decir, existe una previsión legal que ordena que la "aplicación" de las medidas del derecho de excepción sea proporcionada a las circunstancias. El legislador exige la necesidad de la medida con el fin específico de "restablecer la 
normalidad" y recoge la proporcionalidad en un sentido genérico de "prohibición de exceso del poder gubernativo", sin mayor especificidad que circunscribirla a las circunstancias concretas ${ }^{69}$. Esto último se desprende del hecho de que el artículo habla de "aplicación proporcionada" a las circunstancias, no de adopción general y abstracta de la medida. Por tanto, la regla de la proporcionalidad es una exigencia de caso concreto en el momento de aplicación de la restricción. La LO 4/1981 no determina en detalle las posibles restricciones a la libertad deambulatoria durante el estado de alarma, sino que deja a la proporcionalidad esta función, otorgándole un papel central en la limitación de derechos ${ }^{70}$.

En el preámbulo del Real Decreto 463/2020, por el que se declara el estado de alarma en marzo de 2020 se puede leer:

"Las medidas que se contienen en el presente real decreto son las imprescindibles para hacer frente a la situación, resultan proporcionadas a la extrema gravedad de la misma y no suponen la suspensión de ningún derecho fundamental, tal y como prevé el artículo 55 de la Constitución".

Esta fórmula es reproducida en idénticos términos por el Real Decreto 926/2020, por el que se declara el estado de alarma en octubre de 2020, si bien es cierto que, en esta ocasión, la norma es mucho más prolija en la exposición de motivos que respaldan el nuevo estado de alarma, aludiendo a datos y confrontando la realidad de las cifras de la pandemia con el objetivo de preservar la salud pública. A la adecuación, la necesidad y la proporcionalidad de las medidas, en cita de diversas sentencias del Tribunal Constitucional, se refieren también los preámbulos y exposiciones de motivos de los sucesivos reales decretos que han prorrogado los estados de alarma. El propio Tribunal Constitucional se

69 Téngase en cuenta que la regulación legislativa del estado de alarma es del año 1981 y que todavía no se había incorporado el principio de proporcionalidad alemán a nuestra doctrina constitucional de forma clara. Esto no sucederá hasta la STC 66/1995. Tribunal Constitucional (Sala Segunda). Sentencia núm. 66/1995, de 8 de mayo, FJ 4 y 5.

70 Francisco Velasco Caballero, "Libertad, COVID-19 y proporcionalidad (I): fundamentos para un control de constitucionalidad", Blog de Francisco Velasco. Blog independiente, 30 de mayo de 2020, acceso el 18 de diciembre de 2020, https://franciscovelascocaballeroblog.wordpress.com/2020/05/30/libertad-covid-19-y-proporcionalidad-i-fundamentos-para-un-control-de-constitucionalidad/ 
ha pronunciado sobre la proporcionalidad de las medidas en su Auto de 30 abril de 2020 respecto a la tutela del derecho de manifestación ${ }^{71}$.

Es constatable, por tanto, el hecho de que la proporcionalidad en la limitación de los derechos fundamentales es una exigencia constitucional y que la autoridad pública competente de decretar el derecho de excepción se ha manifestado en este sentido para justificar la adopción de las medidas de los arts. 11 y 12 de la LO 4/1981. Siendo así, la proporcionalidad no es sólo un medio de control judicial para evitar abusos de poder. Está en otros momentos de la producción normativa. Se trata de un mecanismo útil para garantizar la mínima interferencia en los derechos de las personas.

Nos preguntamos ahora si la proporcionalidad puede potenciar su funcionalidad para el aseguramiento de los "límites de los límites de los derechos fundamentales” en la coyuntura de crisis sanitaria actual. Es decir, si más allá de la justificación general que dan las exposiciones de motivos de los decretos de alarma y prórroga se podría utilizar de una forma más amplia para paliar las insuficiencias legislativas y problemas constitucionales relativos a la extensión, duración, intensidad y control de las medidas, sobre todo cuando actúan las autoridades sanitarias autonómicas en el ejercicio de sus competencias.

La proporcionalidad como límite y control de la intervención de los poderes públicos opera generalmente en la fase judicial y, más concretamente, en el control de la constitucionalidad de las normas con rango de ley. Este hecho no impide que el principio no pueda ser utilizado también en otras sedes cuando la coyuntura jurídico-política lo aconseje, como evidencian los preámbulos de los decretos del estado de alarma y la incorporación del requisito de la proporcionalidad en algunas leyes en los últimos años ${ }^{72}$. Así, ante la insuficiencia legislativa del derecho de excepción relativa a la intensidad, extensión y duración de las medidas restrictivas de derechos, una alternativa puede ser la aplicación de

71 Francisco Velasco Caballero, "Sobre la ratificación judicial de las medidas sanitarias contra el COVID19", Revista del Consejo General de la Abogacía Española 123 (2020): 10-12. Miguel Ángel Presno Linera, "Fortalezas...", 51-52.

72 Por ejemplo, Ley Orgánica 4/2015, de 30 de marzo, de protección de la seguridad ciudadana, BOE núm. 77 de 31 de marzo de 2015. Vid. el parágrafo II de su exposición de motivos. 
la proporcionalidad en fase legislativa. En el caso de las medidas adoptadas por las autoridades gubernativas tanto estatales como autonómicas, bajo el amparo del estado de alarma, supondría una justificación pormenorizada (no general) de la pertinencia de cada medida en clave de proporcionalidad por parte de la autoridad competente en dictarlas.

Esto implicaría un análisis detallado de la adecuación de la medida, fijando primero el fin que se pretende lograr, el cual debe ser un bien constitucionalmente protegido. En este caso preservar la salud pública (art. 43.1 CE) y proteger la vida e integridad física de las personas (art. $15 \mathrm{CE}$ ). Aunque también pueden perseguirse propósitos más específicos como no saturar el sistema de salud pública (art. 43.2 CE), garantizar alguna contraprestación o ayuda económica y social (art. $41 \mathrm{CE}$ ), protección de la tercera edad (art. 50 CE), etc. Una vez determinado el fin, habría que analizar la adecuación de la medida adoptada al fin pretendido; justificar que es absolutamente necesaria e imprescindible de modo que no haya alternativa menos lesiva de derechos para el logro del fin; y, por último, ponderar si la limitación produce efectos más beneficiosos que perjuicios. Estaríamos ante una aplicación de la proporcionalidad ab initio para los supuestos específicos derivados de la pandemia tanto a nivel general como en cada territorio. $Y$ en este contexto tendría que operar en base al grado de certeza que arrojasen los datos de la situación de emergencia y las previsiones de los expertos sobre ellos. El fin último sería la preservación de la salud pública y de la vida de las personas, pero podrían concurrir otros propósitos constitucionales específicos en cada medida excepcional.

Este examen pormenorizado de cada medida podría dotar de cierta garantía la adopción de las restricciones, y sentar la línea roja de la extensión, intensidad y duración de las medidas limitativas. La garantía se encuentra en el hecho de que la proporcionalidad es un método estructurado que podría dotar de cierto orden lógico al fundamento de la adopción de la medida, esto es, podría sistematizar la actuación discrecional de la autoridad gubernativa para justificar su razón de ser, su necesidad y su extensión. 
La justificación de las disposiciones en clave de proporcionalidad en la fase de elaboración de las normas restrictivas no dificulta ni impide el control parlamentario procedente, ni mucho menos la ratificación judicial posterior o cualquier otro mecanismo de control de la constitucionalidad del derecho de excepción. Asimismo, tampoco exime de responsabilidad a las autoridades por sus actuaciones. Es meramente una garantía más en tiempos excepcionales para coadyuvar a la menor injerencia en la esfera de protección de los derechos de las personas.

La aplicación de esta técnica puede resultar útil a la hora de sentar el precedente de evaluaciones y controles posteriores. En el caso del control de constitucionalidad de los decretos que declaran el estado de alarma, porque avanzan las alegaciones de las autoridades que lo defienden para el caso de que sea impugnada la constitucionalidad ante el Tribunal Constitucional, principalmente por lo dilatado de los tiempos de resolución del Órgano. De otro lado, en el supuesto de la ratificación de medidas adoptadas por las autoridades sanitarias de ámbito inferior al estatal, porque facilita el aval o denegación de los Tribunales Superiores de Justicia, que, además, sólo tienen competencia y obligación de ratificar o rechazar, pero que no tienen por qué analizar la constitucionalidad de la medida o la justificación de la interferencia en los derechos de las personas. Esta función escapa de su cometido, del momento e iter procesal concreto y, además, es inasumible en condiciones de fiabilidad en el breve plazo de tres días en el que deben ratificar73.

En condiciones de urgencia tampoco sería factible que las autoridades competentes se detuvieran a un análisis pormenorizado de las limitaciones de derechos y de su posible constitucionalidad, pero no olvidemos que el contexto actual, y uno de los problemas que apuntábamos en epígrafes anteriores, reside en el dato de que la excepcionalidad de la situación se ha alargado significativamente, generando más dudas e incertidumbres que certezas. Es en esta

73 Tribunal Constitucional (Sala Primera). Auto núm. 40/2020, de 30 de abril, FFJJ 4 y 5. 
coyuntura en la que proponemos la adopción de medidas en clave de proporcionalidad con un examen detallado.

Por tanto, el principio de proporcionalidad funcionaría:

1. Como principio integrador del derecho para cubrir las carencias e insuficiencias legales, instaurando un método ordenado con el que descartar las restricciones excesivas y no necesarias para el fin que se pretende.

2. Como método interpretativo para fijar los "límites" de la acción gubernativa limitadora de derechos, lo que permite determinar la conveniencia y legitimidad de la medida restrictiva en abstracto, sin perjuicio del control posterior por las fórmulas previstas en el ordenamiento jurídico.

En definitiva, ¿qué aportaría esta aplicación de la proporcionalidad a los problemas concretos que hemos planteado?

Primero. La aplicación del principio de proporcionalidad ab initio sería una garantía más del estado de derecho en el respeto y la protección a los derechos de las personas.

Segundo. La fórmula estructurada y el orden lógico del principio contribuirían a sistematizar el proceso de adopción de las medidas restrictivas a partir de un silogismo racional capaz de determinar la pertinencia de la restricción de forma razonada74.

Tercero. La mera aplicación de la proporcionalidad en todas sus fases para justificar la adopción de una medida específica en el contexto del estado de alarma continuado, ponderando los bienes constitucionales en juego, conllevaría de suyo que la libertad en general no está suspendida, sino limitada para el

74 Partimos aquí de la concepción de la proporcionalidad como "método de aplicación del derecho" en el sentido apuntado por el profesor Martin Borowski, en el conocimiento de las críticas al método por quienes consideran que no existen "estándares de racionalidad" y que la ponderación adolece de subjetivismo. Vid. Martin Borowski, "Derechos absolutos y proporcionalidad", Revista Derecho del Estado 48 (2021): 304-306. Sobre las críticas, cfr. Thomas Alexander Aleinikoff, "Constitutional Law in the Age of Balancing”, Yale Law Journal 96 (1986-1987): 948-972. 
logro de intereses relevantes para el estado y la sociedad, como son la vida y la salud de las personas.

Cuarto. Además, en esta situación de excepcionalidad continuada puede ser una fórmula eficaz para mesurar las acciones concretas de las autoridades gubernativas autonómicas bajo el amparo de la declaración del estado de alarma. Esto se debe a que es una técnica que se cohonesta perfectamente con las amplias facultades discrecionales que el segundo estado de alarma durante la pandemia contempla para las Comunidades Autónomas.

En definitiva, aunque la adopción de medidas en clave de proporcionalidad no solucione toda la problemática constitucional planteada, ofrece una vía para racionalizar y justificar la limitación de derechos, colmando ciertas insuficiencias legales.

\section{CONCLUSIONES}

El desarrollo legislativo del derecho de excepción en España adolece de insuficiencias, dejando mucho margen a la interpretación y pocas certezas. Es preciso una renovación legislativa para adaptarse a la nueva realidad jurídico-política y territorial del estado español. Las necesidades sanitarias y sociales de la pandemia han evidenciado la problemática constitucional y jurídica de un derecho de excepción alargado en el tiempo, que genera más inquietudes que soluciones, al menos, en lo que a las garantías del estado social y democrático de derecho se refiere.

No cabe duda de que el presupuesto de hecho que ha habilitado el derecho de excepción ha sido una pandemia de dimensiones globales. Es por ello que la fórmula de derecho excepcional que procedía era un estado de alarma y no un estado de excepción, pues no se ha constatado la alteración del orden público ni una suspensión generalizada de los derechos de las personas ni de sus garantías.

La interferencia de los poderes públicos en la esfera de los derechos y libertades ciudadanas ha tenido su encaje en las posibilidades de limitación de derechos recogidas en la legislación aplicable, justificándose en la protección de la 
salud pública y de la vida y la integridad física de las personas. Sin embargo, es cuestionable la intensidad, extensión y duración de las medidas, así como su régimen de control.

Para garantizar la legitimidad constitucional de las limitaciones se ha abogado doctrinal, legislativa y jurisprudencialmente por la aplicación del principio de proporcionalidad en cuanto a garantía de que las restricciones se usan en su justa medida para el logro del fin propuesto. Y ello, en la plena consciencia de las críticas que la técnica pueda suscitar, particularmente respecto a la subjetividad de la ponderación de los bienes constitucionales contrapuestos.

La proporcionalidad es un método interpretativo de carácter estructural que funciona como límite a las interferencias de los poderes públicos en los derechos fundamentales y libertades públicas. Es una herramienta muy útil para acotar la esfera de protección del derecho y medir el alcance de su zona de interferencia cuando éste entra en colisión con otro derecho o con la protección de un bien constitucionalmente protegido a través de alguna medida controvertida. La proporcionalidad se ha convertido en un criterio general de constitucionalidad para medir y evitar la arbitrariedad y los abusos de poder, a pesar de no estar recogida en el texto constitucional.

La proporcionalidad no opera sólo en sede jurisdiccional o en el ámbito de control de la constitucionalidad. Constituye un fundamento necesario de la justificación de los límites a los derechos fundamentales, siendo un requisito imprescindible en la adopción de medidas gubernativas o legislativas restrictivas de derechos. Así se ha constatado en los decretos de declaración del estado de alarma, en la opinión de la doctrina mayoritaria y en la interpretación del Tribunal Constitucional. Es por ello que consideramos que una renovación legislativa del derecho de excepción, debería tener en cuenta la exigencia de proporcionalidad entre los requisitos de adopción de medidas limitativas y suspensivas de derechos.

Por último, la proporcionalidad parece una alternativa factible para justificar el alcance de las medidas limitativas de los derechos fundamentales en una situación de excepcionalidad prolongada a través de un examen pormenorizado 
e individualizado de cada medida en la fase de elaboración. De esta forma la proporcionalidad desarrolla una función de principio integrador del derecho. Redactar las disposiciones limitativas de derechos en clave de proporcionalidad ofreciendo argumentos sólidos sobre el propósito de la restricción, la idoneidad de la medida para lograrlo, su necesaria aplicación y la ponderada reducción del derecho, ofrece cierta certeza jurídica sobre la legitimidad constitucional de la actuación gubernativa o legislativa y facilita en algún grado el posterior control parlamentario, jurisprudencial o constitucional, según proceda. Además, la fórmula estructurada y el orden lógico del principio sirven para sistematizar el proceso de adopción de las medidas restrictivas en base a criterios de razonabilidad.

La proporcionalidad no se trata de una panacea universal para la solución de los problemas constitucionales del derecho de excepción y de afectación de los derechos, pero, a falta de otras alternativas, es un instrumento útil para asegurar la legitimidad constitucional de las medidas.

\section{REFERENCIAS BIBLIOGRÁFICAS}

Aba Catoira, Ana. "El estado de alarma en España", Teoría y realidad constitucional 28 (2011): 305-334.

Aguiar Luque, Luis. "Los límites de los derechos fundamentales". Revista del Centro de Estudios Constitucionales 14 (1993), 9-34.

Aleinikoff, Thomas Alexander. "Constitutional Law in the Age of Balancing". Yale Law Journal 96 (1986-1987): 948-972.

Alexy, Robert. Teoría de los derechos fundamentales. Madrid: Centro de Estudios Políticos y Constitucionales, 1993.

Álvarez García, Vicente. "El coronavirus (COVID-19): respuestas jurídicas frente a una situación de emergencia sanitaria”. El Cronista del Estado Social y Democrático de Derecho 86-87 (2020): 6-21.

Bacigalupo Saggese, Mariano. "La aplicación de la doctrina de los límites inmanentes a los derechos fundamentales sometidos a reserva de limitación legal”. Revista Española de Derecho Constitucional 38 (1993): 297-315.

Barak, Aharon. Proporcionalidad. Los derechos fundamentales y sus restricciones. Lima: Palestra, 2017. 
Barnés Vázquez, Javier. "El principio de proporcionalidad. Estudio preliminar”. Revista Cuadernos de Derecho Público 5 (1998): 15-50.

Bernal Pulido, Carlos. El principio de proporcionalidad y los derechos fundamentales. Madrid: Centro de Estudios Políticos y Constitucionales, 2005.

Borowski, Martin. "Derechos absolutos y proporcionalidad”. Revista Derecho del Estado 48 (2021): 371-402.

Cruz Villalón, Pedro. "El nuevo derecho de excepción (LO 4/1981, de 1 de junio)". Revista Española de Derecho Constitucional 2 (1981): 93-128.

Cruz Villalón, Pedro. Estados excepcionales y suspensión de garantías. Madrid: Tecnos, 1984. Cuenca Miranda, Alfonso. “Alarma excepcional”, Papeles FAES 236 (2020): 1-8.

De Vega García, Pedro. “Comentario al Título X. De la reforma constitucional”. En Constitución española. Edición comentada, dirigido Luis Sánchez Agesta, Pablo Lucas Verdú, Gumersindo Trujillo Fernández y Pedro de Vega García. 359-26o. Madrid: Centro de Estudios Constitucionales, 1979.

De Otto y Pardo, Ignacio. Derechos fundamentales y Constitución. Madrid: Civitas, 1988.

Fernández de Casadevante Mayordomo, Pablo. La defensa de la Constitución. El derecho de emergencia constitucional y el artículo 55 CE. Madrid: Aranzadi, 2020.

Fernández, Casadevante Mayordomo, Pablo. "El derecho de emergencia constitucional en España: hacia una nueva taxonomía”. Revista de Derecho Político 107 (2020): 111-145.

Fernández Nieto, Josefina. Principio de proporcionalidad y derechos fundamentales: una perspectiva desde el derecho común europeo. Madrid: Dykinson, 2008.

Fuentes Cubillos, Hernán. "El principio de proporcionalidad en Derecho Penal. Algunas consideraciones acerca de su concretización en el ámbito de la individualización de la pena”. Ius et praxis 14, 2 (2008): 15-42.

García Cuadrado, Antonio María. El ordenamiento constitucional (un enfoque histórico y formal de la teoría de la Constitución y de las fuentes del derecho. San Vicente de Raspeig: Club universitario, 2002.

Garrido López, Carlos. "La naturaleza bifronte del estado de alarma y el dilema limitaciónsuspensión de derechos”. Teoría y Realidad Constitucional 46 (2020): 371-402.

Goig Martínez, Juan Manuel, "La defensa política de la Constitución. Constitución y estados excepcionales (II). Un estudio de derecho constitucional comparado”, Revista de Derecho UNED 4 (2009): 263-296.

Häberle, Peter. La garantía del contenido esencial de los derechos fundamentales. Madrid: Dykinson, 2003. 
Iglesias Vila, Marisa. "Los conceptos esencialmente controvertidos en la interpretación constitucional". Doxa. Cuadernos de filosofía del derecho 23 (2000): 77-104.

Jiménez Campos, Javier. Derechos fundamentales. Concepto y garantías. Madrid: Trotta, 1999.

Kluth, Winfried. "Prohibición de exceso y principio de proporcionalidad en Derecho alemán”, Revista Cuadernos de Derecho Público 5 (1998): 219-237.

Medina Guerrero, Manuel. La vinculación legislativa del legislador a los derechos fundamentales. Madrid: McGraw Hill, 1997.

Medina Guerrero, Manuel. "El principio de proporcionalidad y el legislador de los derechos fundamentales”. Cuadernos de Derecho Público 5 (1998): 119-141.

Presno Linera, Miguel Ángel. "Fortalezas y debilidades del Derecho de excepción frente al COVID-19”. Jueces para la democracia 99 (2020): 39-52.

Presno Linera, Miguel Ángel. "Estado de alarma y sociedad del riesgo global”. En Las respuestas del derecho a las crisis de salud pública, dirigido por Elena Atienza Macías y Juan Francisco Rodríguez Ayuso. 15-28. Madrid: Dykinson, 2020.

Prieto Sanchís, Luis. Justicia constitucional y derechos fundamentales. Madrid, Trotta, 2003.

Santamaría Pastor, Juan Alfonso. "Notas sobre el ejercicio de las potestades normativas en tiempos de pandemia”. En Derecho Público (durante el estado de alarma y más allá), dirigido por David Blanquer Criado. 207-240. Valencia: Tirant lo Blanch, 2020.

Santaolalla López, Fernando. “Crónica parlamentaria”. Revista española de Derecho Constitucional 2 (1981): 249-282.

Sarmiento Ramírez-Escudero, Daniel. El control de proporcionalidad en la actividad administrativa. Valencia: Tirant lo Blanc, 2004.

Serrano Alberca, José Manuel. “Comentario al artículo 116”. En Comentarios a la Constitución, dirigido por Fernando Garrido Falla. 1764-1817. $3^{\text {a }}$ edición. Madrid: Civitas, 2001.

Velasco Caballero, Francisco. "Sobre la ratificación judicial de las medidas sanitarias contra el COVID-19”. Revista del Consejo General de la Abogacía Española 123 (2020): 10-12. Velasco Caballero, Francisco. "Estado de alarma y distribución territorial del poder". El Cronista del Estado Social y Democrático de Derecho 86-87 (2020): 78-87.

Anexo de legislación

Constitución española, BOE núm. 311, de 29 de diciembre de 1978. 
Ley Orgánica 4/1981, de 1 de junio, de los estados de alarma, excepción y sitio, BOE núm. 134 de 5 de junio de 1981.

Ley Orgánica 4/2015, de 30 de marzo, de protección de la seguridad ciudadana, BOE núm. 77 de 31 de marzo de 2015.

Ley 3/1986, de 14 de abril, de medidas especiales en materia de salud pública, BOE núm. 102 de 29 de abril de 1986.

Ley 33/2011, de 4 de octubre, general de salud pública, BOE núm. 240 de 5 de octubre de 2011.

Ley 3/2020, de 18 de septiembre, de medidas procesales y organizativas para hacer frente al COVID-19 en el ámbito de la Administración de Justicia, BOE núm. 250 de 19 de septiembre de 2020.

Real Decreto 463/2020, de 14 de marzo, por el que se declara el estado de alarma para la gestión de la situación de crisis sanitaria ocasionada por el COVID-19, Boletín Oficial del Estado, en adelante, BOE núm. 67 de 14 de marzo de 2020.

Real Decreto 1673/2010, de 4 de diciembre, por el que se declara el estado de alarma para la normalización del servicio público esencial del transporte aéreo, BOE núm. 295 de 4 de diciembre de 2010.

Real Decreto 476/2020, de 27 de marzo, por el que se prorroga el estado de alarma declarado por el Real Decreto 463/2020, de 14 de marzo, por el que se declara el estado de alarma para la gestión de la situación de crisis sanitaria ocasionada por el COVID-19, BOE núm. 86, de 28 de marzo de 2020.

Real Decreto 487/2020, de 10 de abril, por el que se prorroga el estado de alarma declarado por el Real Decreto 463/2020, de 14 de marzo, por el que se declara el estado de alarma para la gestión de la situación de crisis sanitaria ocasionada por el COVID-19, BOE núm. 101, de 11 de abril de 2020.

Real Decreto 492/2020, de 24 de abril, por el que se prorroga el estado de alarma declarado por el Real Decreto 463/2020, de 14 de marzo, por el que se declara el estado de alarma para la gestión de la situación de crisis sanitaria ocasionada por el COVID-19, BOE núm. 115, de 25 de abril de 2020.

Real Decreto 514/2020, de 8 de mayo, por el que se prorroga el estado de alarma declarado por el Real Decreto 463/2020, de 14 de marzo, por el que se declara el estado de alarma para la gestión de la situación de crisis sanitaria ocasionada por el COVID-19, BOE núm. 129, de 9 de mayo de 2020. 
Real Decreto 537/2020, de 22 de mayo, por el que se prorroga el estado de alarma declarado por el Real Decreto 463/2020, de 14 de marzo, por el que se declara el estado de alarma para la gestión de la situación de crisis sanitaria ocasionada por el COVID-19, BOE núm. 145, de 23 de mayo de 2020.

Real Decreto 555/2020, de 5 de junio, por el que se prorroga el estado de alarma declarado por el Real Decreto 463/2020, de 14 de marzo, por el que se declara el estado de alarma para la gestión de la situación de crisis sanitaria ocasionada por el COVID-19, BOE núm. 159, de 6 de junio de 2020.

Real Decreto 926/2020, de 25 de octubre, por el que se declara el estado de alarma para contener la propagación de infecciones causadas por el SARS-CoV-2, BOE núm. 282 de 25 de octubre de 2020.

Real Decreto 956/2020, de 3 de noviembre, por el que se prorroga el estado de alarma declarado por el Real Decreto 926/2020, de 25 de octubre, por el que se declara el estado de alarma para contener la propagación de infecciones causadas por el SARS-CoV-2, BOE núm. 291 de 4 de noviembre de 2020.

Resolución de 24 de febrero de 1982 por la que se ordena la publicación en el Boletín Oficial del Estado del nuevo Reglamento del Congreso de los Diputados, BOE núm. 55 de 5 de marzo de 1982.

Anexo de jurisprudencia

Tribunal Constitucional (Pleno). Sentencia núm. 37/1981, de 16 de noviembre.

Tribunal Constitucional (Pleno). Sentencia núm. 108/1986, de 29 de julio.

Tribunal Constitucional (Pleno). Sentencia núm. 65/1990, de 5 de abril.

Tribunal Constitucional (Pleno). Sentencia núm. 142/1993, de 22 de abril.

Tribunal Constitucional (Sala Primera). Sentencia núm. 50/1995, de 23 de febrero.

Tribunal Constitucional (Sala Segunda). Sentencia núm. 66/1995, de 8 de mayo.

Tribunal Constitucional (Pleno) Sentencia núm. 46/2001, de 15 de febrero.

Tribunal Constitucional (Sala Primera). Sentencia núm. 177/2002, de 14 de octubre.

Tribunal Constitucional (Sala Primera). Sentencia núm. 40/2003, de 27 de febrero.

Tribunal Constitucional (Pleno). Sentencia núm. 84/2013, de 11 de abril.

Tribunal Constitucional (Pleno). Sentencia núm. 83/2016, de 28 de abril.

Tribunal Constitucional (Pleno). Sentencia núm. 76/2019, de 22 de mayo.

Tribunal Constitucional (Sala Primera). Auto núm. 40/2020, de 30 de abril.

Tribunal Superior de Justicia de Galicia (Sala de lo contencioso-administrativo, Sección $1^{\text {a }}$ ).

Sentencia núm. 136/2020, de 28 de abril de 2020. 
Tribunal Superior de Justicia de Aragón (Sala de lo contencioso-administrativo, Sección

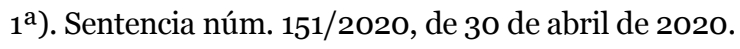

Tribunal Superior de Justicia de Navarra (Sala de lo contencioso-administrativo, Sección

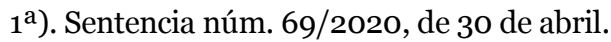

Tribunal Superior de Justicia de Extremadura (Sala de lo contencioso-administrativo, Sección $1^{\text {a }}$ ). Sentencia núm. 118/2020, de 12 de mayo de 2020

Tribunal Superior de Justicia de Madrid (Sala de lo contencioso-administrativo, Sección $10^{\mathrm{a}}$ ). Sentencia núm. 214/2020, de 21 de mayo.

Tribunal Superior de Justicia de Galicia (Sala de lo contencioso-administrativo, Sección $3^{\text {a }}$ ). Auto núm. 83/2020, de 23 de septiembre de 2020.

Tribunal Superior de Justicia de Andalucía (Sala de lo contencioso-administrativo, Sección $1^{\mathrm{a}}$ ). Auto núm. 220/2020, de 2 de octubre de 2020.

Tribunal Superior de Justicia de Aragón (Sala de lo contencioso-administrativo, Sección $\left.1^{\circ}\right)$. Auto núm. 87/2020, de 5 de octubre de 2020.

Tribunal Superior de Justicia de Extremadura (Sala de lo contencioso-administrativo, Sección $1^{\text {a }}$ ). Auto núm. 101/2020, de 5 de octubre de 2020.

Tribunal Superior de Justicia de la Comunidad Valenciana (Sala de lo contenciosoadministrativo, Sección $4^{\text {a }}$ ). Auto núm. 130/2020, de 6 de octubre de 2020

Tribunal Superior de Justicia de Madrid (Sala de lo contencioso-administrativo, Sección $8^{\mathrm{a}}$ ). Auto núm. 128/2020 de 8 de octubre de 2020.

Tribunal Superior de Justicia de la Comunidad Valenciana (Sala de lo contenciosoadministrativo, Sección $4^{\text {a }}$ ). Auto núm. 142/2020, de 27 de octubre de 2020

Tribunal Superior de Justicia de Castilla y León (Sala de lo contencioso-administrativo, Sección $1^{\text {a }}$ ). Auto núm. 297/2020, de 6 de noviembre de 2020.

Tribunal Superior de Justicia de Aragón Sala de lo contencioso-administrativo, Sección $1^{\text {a }}$ ). Auto del procedimiento ordinario núm. 332/2020, de 3 de diciembre de 2020.

Tribunal de Justicia de la Unión Europea. Sentencia de 29 de noviembre de 1956, Fédération Charbonnière de Belgique, asunto 8/55.

Lorena Chano Regaña Área de Derecho Constitucional Departamento de Derecho Público Facultad de Derecho Universidad de Extremadura lorenachano@unex.es https://orcid.org/o000-0002-7475-3852 
